\title{
THE INHERITANCE OF RESISTANCE TO RHYNCHOSPORIUM SECALIS IN BARLEY
}

\author{
R. M. HABGOOD and J. D. HAYES \\ Welsh Plont Breeding Station, Aberystwyth, Wales
}

Received 12.vii. 70

\section{INTRODUCTION}

Several studies have been carried out, mainly in the U.S.A., on the inheritance of resistance to the leaf blotch (or scald) disease of barley, caused by Rhynchosporium secalis (Oudem.) J. J. Davies. Mackie (1929) found that resistance in an unspecified variety was controlled by a single recessive gene. Riddle and Briggs (1950) identified a single dominant gene conferring resistance in $\mathrm{La}$ Mesita, which was also present with a recessive gene in Trebi and California 1311 ( $=$ Modoc), and with one or more additional dominant genes in Turk. A designation for genes conferring resistance to $R$. secalis was first used by Bryner (1957), who allocated the symbol Rha (later amended to $R h$ by Robertson, 1960) to a dominant gene found in Brier.

Dyck and Schaller (196la) isolated a further five dominant genes for resistance, which were designated $R h 2$ (in Atlas and Atlas 46), Rh3 (in Atlas 46 and Turk), Rh4 (in La Mesita, Osiris and Trebi), $R h 4^{2}$ (an allele at the $R h 4$ locus, in Modoc) and Rh5 (in Turk). These genes were shown to be specific against certain races of the pathogen. The $R h 3$ and $R h 4$ loci were very closely linked on chromosome 3 (Dyck and Schaller, 196la,b), and $R h 3$ was considered to be identical, allelic or closely linked to the $R h$ locus in Brier.

A pair of complementary recessive genes, $r h 6$ and $r h 7$, in 7 et and Steudelli, and an incompletely dominant gene, Rh9, in Kitchin and C.I. 668, were found by Baker and Larter (1963), who also confirmed the presence of a single dominant gene in Turk. Wells and Skoropad (1963) identified a recessive gene for resistance in Nigrinudum, designated $r h 8$, and a dominant gene, considered to be $R h 3$, on chromosome 3 of Turk; this same gene, or one closely linked to it, was also found in Bey, Rivale, 36Ab 1991, C.I. 3515, C.I. 8256 and Osiris. Frecha (1967) found that the varieties Osiris, Psaknon and Atrada $\times$ Atlas ( = Atlas 46) had a dominant gene for resistance in common, and that the latter variety also had an additional dominant gene.

The results of a study on 23 varieties by Starling et al. (1971) suggested that Atlas 46, Turk, Brier, La Mesita, Modoc, Gembloux 14, Alaska (C.I. 534 and C.I. 4106), Tennessee Winter (C.I. 876), Kentucky No. 36, Olympia, Tschermak, Hudson, Carstens 2-row, C.I. 3515, C.I. 8071, C.I. 8101, C.I. 8256, C.I. 9042 and C.I. 10176 all had a single gene or gene locus in common. Atlas 46 had an additional gene which was also found in Atlas, and C.I. 3515 also had an additional dominant gene, different to that found in Atlas. C.I. 8618 was found to contain a dominant gene not found in any other variety tested.

In Britain, Evans (1969) detected a single dominant gene for resistance in Atlas 46, Turk and Osiris; since these genes were either allelic or closely linked, they were presumed to be $R h 3$ in the first two varieties and $R h 4$ in the last. 
In most of the studies cited above, no recombination was observed in $\mathrm{F}_{2}$ or $\mathrm{F}_{3}$ progeny from crosses between two resistant varieties. The use of small test populations and/or single isolates of $R$. secalis frequently made it impossible to verify whether the genes in the two varieties were allelic, closely linked or identical. Consequently, the genetic diversity of host resistance, and hence the potential of the available resistance sources for breeding purposes, cannot be determined.

\section{Materials And methods}

The 18 barley varieties used in this experiment gave the reactions shown in table 1 when inoculated with three isolates of $R$. secalis provided by $\mathrm{Dr} H$.

TABLE 1

The reactions of 18 barley varieties to three isolates of $\mathrm{R}$. secalis

\begin{tabular}{rlc}
\multicolumn{3}{c}{ Variety } \\
\hline Cb* & & C.I. $\dagger$ \\
763 & Proctor & - \\
1098 & Maris Otter & - \\
1084 & Wisc. W. $\times$ Glabron & 8162 \\
957 & Turk & $5611-2$ \\
952 & Atlas 46 & 7323 \\
1080 & Brier & 7157 \\
1081 & Hudson & 8067 \\
1092 & Dea & - \\
1085 & Modoc & 7566 \\
956 & Osiris & 1622 \\
1086 & La Mesita & 7565 \\
1105 & & 3515 \\
1106 & & 8256 \\
1107 & Gembloux 14 & 8286 \\
1087 & Fet & 967 \\
1149 & Nigrinudum & 11797 \\
1089 & & 4364 \\
1090 & & 4368
\end{tabular}

\begin{tabular}{ccc}
\multicolumn{3}{c}{ Isolates } \\
& 1435 & 1436 \\
$\mathrm{~S}$ & $\mathrm{~S}$ & $\mathrm{~S}$ \\
$\mathrm{~S}$ & $\mathrm{~S}$ & $\mathrm{~S}$ \\
$\mathrm{R}$ & $\mathrm{R}$ & $\mathrm{S}$ \\
$\mathrm{R}$ & $\mathrm{R}$ & $\mathrm{S}$ \\
$\mathrm{R}$ & $\mathrm{R}$ & $\mathrm{S}$ \\
$\mathrm{R}$ & $\mathrm{R}$ & $\mathrm{S}$ \\
$\mathrm{R}$ & $\mathrm{R}$ & $\mathrm{S}$ \\
$\mathrm{R}$ & $\mathrm{R}$ & $\mathrm{S}$ \\
$\mathrm{R}$ & $\mathrm{S}$ & $\mathrm{S}$ \\
$\mathrm{R}$ & $\mathrm{R}$ & $\mathrm{R}$ \\
$\mathrm{R}$ & $\mathrm{R}$ & $\mathrm{R}$ \\
$\mathrm{R}$ & $\mathrm{R}$ & $\mathrm{R}$ \\
$\mathrm{R}$ & $\mathrm{R}$ & $\mathrm{R}$ \\
$\mathrm{R}$ & $\mathrm{R}$ & $\mathrm{R}$ \\
$\mathrm{R}$ & $\mathrm{R}$ & $\mathrm{S}$ \\
$\mathrm{R}$ & $\mathrm{R}$ & $\mathrm{S}$ \\
$\mathrm{R}$ & $\mathrm{R}$ & $\mathrm{S}$ \\
$\mathrm{R}$ & $\mathrm{R}$ & $\mathrm{S}$
\end{tabular}

* Accession Number Arable Crop Breeding Department, Welsh Plant Breeding Station, Aberystwyth.

† Accession Number Cereal Crops Research Branch, A.R.S., U.S.D.A., Beltsville, Maryland.

Owen, University of Reading. These isolates were selected as being representative of the pathogenic variation available in Britain. On the basis of these results, a hybridisation programme was devised from which $F_{1}, F_{2}$ or $F_{3}$ progeny were obtained for testing. The $\mathbf{F}_{\mathbf{1}}$ hybrids were grown in the glasshouse and, with the exception of the crosses between Turk, Atlas 46 and Osiris, all $\mathrm{F}_{\mathbf{1}}$ hybrid plants were protected at anthesis to ensure that no outcrossing occurred. The $\mathrm{F}_{3}$ families were obtained from spaced $\mathrm{F}_{2}$ plants grown in the field, which were not protected against outcrossing.

The reactions of progeny to $R$. secalis were determined by tests on seedlings. These were sown in rows $40 \mathrm{~mm}$. apart in shallow boxes of sterile compost, in a glasshouse maintained at $10^{\circ}$ to $20^{\circ} \mathrm{C}$. The parent and $\mathrm{F}_{2}$ plants were spaced about $20 \mathrm{~mm}$. apart, $\mathrm{F}_{1}$ hybrids $35 \mathrm{~mm}$. apart, and each $\mathrm{F}_{3}$ family consisted of 20-25 plants sown about $10 \mathrm{~mm}$. apart. These plants 
were inoculated 14 days after sowing, when the second leaf had partially emerged.

Inoculum was prepared by growing the cultures of $R$. secalis on 2 per cent. lima bean agar (Schein and Kerelo, 1956) in $250 \mathrm{ml}$. medical flat bottles to which $10 \mathrm{ml}$. sterile distilled water was added at the time of seeding (Sarasola and Campi, 1947). After incubation at $18^{\circ} \mathrm{C}$. for 10 days, the mycelial mat was scraped off, macerated in water, and filtered through muslin to remove large mycelial fragments. The conidial concentration was adjusted to $800,000-1,000,000$ per $\mathrm{ml}$., and the suspension sprayed on to the plants. In one cross (Osiris $\times$ Proctor), $\mathrm{F}_{2}$ plants were tested against two isolates simultaneously, by rubbing a conidial suspension of one isolate on to the second leaf and the other on to the third leaf.

Following inoculation, the boxes were placed in a shallow trough of water under a polythene-covered frame for 48 hours to maintain high humidity, and then allowed to dry. Symptoms generally appeared 10-14 days after inoculation, and were scored 4 days after their first appearance. In some cases, a second assessment was made 28 days after inoculation.

Although the reactions of the parent varieties fitted the categories described by Dyck and Schaller (1961a), it was found that in most cases the progeny could be more simply classified as resistant or susceptible on the basis of the first leaf reaction. At the conidial concentrations used in this study, the first leaves of susceptible segregates wilted completely, whilst the resistant ones were unaffected. However, in a few instances, the tips of the first leaves and small areas of the second leaves showed symptoms; this is referred to as a "type 2 " reaction, in contrast to the "type 4 " of complete susceptibility and "type 0 " of complete resistance.

Crosses between two resistant varieties frequently produced $F_{2}$ or $F_{3}$ populations which were completely resistant. In such cases, the genes in the two varieties could either be allelic or linked too closely for a recombinant to be detected in the population tested. The maximum recombination frequency which could have passed undetected (at $\mathrm{P}=0.05$ ) was calculated from the formula outlined by Hanson (1959), viz.:

$$
P_{r c}=1-n \sqrt{0 \cdot 05}
$$

where $n$ is the number of $\mathrm{F}_{2}$ plants or $\mathrm{F}_{3}$ families tested, and $P_{r c}$ is the proportion of detectable recombinants. With two genes in repulsion, this is equal to $p^{2} / 4$ in the $\mathrm{F}_{2}$ generation and $\left(4 p-p^{2}\right) / 4$ in the $\mathrm{F}_{3}$ generation. The same formula was also used when $\mathrm{F}_{2}$ plants were tested simultaneously against two isolates of the pathogen, to determine whether one or two genes were involved. For two genes in coupling, $P_{r c}$ is equal to $\left(2 p-p^{2}\right) / 2$.

The location of the resistance genes in Turk and Osiris was determined from crosses between these varieties and stocks homozygous for the chromosome 3 recessive marker genes "streaked" (Stst) which produces streaked seedlings, and "uzu" (Uzuz), which produces dwarf plants recognisable in the seeding stage, and the chromosome interchange stock T2-3d. These were tested for resistance and the marker character or semi-sterility in $\mathrm{F}_{2}$ or $\mathrm{F}_{3}$ in the field or glasshouse, as indicated in the results. Linkages between resistance genes and marker genes were calculated by the product method, using tables by Fisher and Yates (1963), and between resistance genes and the T2-3d break-point using tables given by Joachim (1947). 


\section{Results}

The $\mathrm{F}_{2}$ progeny from a cross between $\mathrm{Cb} 1084$ (Wisconsin Winter $\times$ Glabron) and Proctor segregated to give a good fit of 3 resistant : 1 susceptible plants when assessed 14 days after inoculation with isolate 1394 of $R$. secalis (table 2).

TABLE 2

The reaction of progeny from crosses involving $C b 1084$ to isolate 1394 of $\mathrm{R}$. secalis

\begin{tabular}{|c|c|c|c|c|c|c|c|}
\hline \multirow[b]{2}{*}{ Cross } & \multirow[b]{2}{*}{ Generation } & \multirow{2}{*}{$\begin{array}{c}\text { Days } \\
\text { after } \\
\text { inoculation }\end{array}$} & \multicolumn{3}{|c|}{$\begin{array}{l}\text { Frequency of } \\
\text { reaction types }\end{array}$} & \multirow{2}{*}{$\begin{array}{c}\text { Expected } \\
\text { ratio }\end{array}$} & \multirow[b]{2}{*}{ Probability } \\
\hline & & & 0 & 2 & 4 & & \\
\hline $\begin{array}{ll}C b & 1084 \times \text { Proctor } \\
C b & 1084 \times \text { Proctor }\end{array}$ & $\begin{array}{l}\mathrm{F}_{2} \\
\mathrm{~F}_{2}\end{array}$ & $\begin{array}{l}14 \\
28\end{array}$ & $\begin{array}{r}263 \\
22\end{array}$ & $\begin{array}{r}0 \\
35\end{array}$ & $\begin{array}{r}105 \\
22\end{array}$ & $\begin{array}{l}3: 0: 1 \\
1: 2: 1\end{array}$ & $\begin{array}{l}0 \cdot 1-0 \cdot 2 \\
0.5-0 \cdot 7\end{array}$ \\
\hline
\end{tabular}

When re-assessed 28 days after inoculation, a number of resistant plants had developed type 2 symptoms, and the final ratio did not deviate significantly from 1 (type 0 ) : 2 (type 2) : 1 (type 4). This suggests that the resistance of $C b 1084$ is controlled by a single gene which is incompletely dominant,

TABLE 3

The reaction of $F_{2}$ and $F_{3}$ progeny from crosses involving Turk, Atlas 46 , Brier, Hudson, Dea and Modoc to isolate 1394 of R. secalis

\begin{tabular}{|c|c|c|c|c|c|c|c|}
\hline \multirow[b]{2}{*}{ Cross } & \multirow[b]{2}{*}{ Generation } & \multirow{2}{*}{$\begin{array}{c}\text { Days } \\
\text { after } \\
\text { inoculation }\end{array}$} & \multicolumn{3}{|c|}{$\begin{array}{l}\text { Observed } \\
\text { frequency }\end{array}$} & \multirow[b]{2}{*}{$\begin{array}{c}\text { Expected } \\
\text { ratio }\end{array}$} & \multirow[b]{2}{*}{ Probability } \\
\hline & & & Res. & Seg. & Sus. & & \\
\hline Turk $\times$ Proctor & $F_{2}$ & 14 & 105 & - & 37 & $3: 1$ & $0 \cdot 7-0 \cdot 8$ \\
\hline Turk $\times$ Proctor & $\mathrm{F}_{3} \mathrm{f} *$ & $14 \& 28$ & 18 & 52 & 20 & $1: 2: 1$ & $0 \cdot 3-0.5$ \\
\hline Turk $\times$ Proctor & $\mathrm{F}_{3} \mathrm{~s}^{*}$ & $14 \& 28$ & 832 & - & 295 & $3: 1$ & $0.3-0.5$ \\
\hline Atlas $46 \times$ Proctor & $F_{2}$ & $14 \& 28$ & 111 & 一 & 29 & $3: 1$ & $0 \cdot 2-0 \cdot 3$ \\
\hline Atlas $46 \times$ Proctor & $\mathrm{F}_{3} \mathrm{f}$ & $14 \& 28$ & 16 & 49 & 18 & $1: 2: 1$ & $0 \cdot 2-0 \cdot 3$ \\
\hline Atlas $46 \times$ Proctor & $\mathrm{F}_{3} \mathrm{~s}$ & $14 \& 28$ & 815 & - & 294 & $3: 1$ & $0 \cdot 2-0 \cdot 3$ \\
\hline Brier $\times$ Proctor & $\mathrm{F}_{2}$ & $14 \& 28$ & 216 & - & 65 & $3: 1$ & $0.3-0.5$ \\
\hline Hudson $\times$ Proctor & $\mathrm{F}_{2}$ & $14 \& 28$ & 231 & 一 & 64 & $3: 1$ & $0 \cdot 1-0 \cdot 2$ \\
\hline Dea $\times$ Maris Otter & $F_{2}$ & $14 \& 28$ & 135 & - & 40 & $3: 1$ & $0 \cdot 2-0 \cdot 3$ \\
\hline Modoc $\times$ Proctor & $F_{2}$ & $14 \& 28$ & 172 & 一 & 63 & $3: 1$ & $0.5-0.7$ \\
\hline Atlas $46 \times$ Turk & $\mathrm{F}_{3} \mathrm{f}$ & 14 & 187 & 0 & 0 & $7: 8: 1$ & $<0.01$ \\
\hline Brier $\times$ Turk & $\mathrm{F}_{3} \mathrm{f}$ & 14 & 189 & 0 & 0 & $7: 8: 1$ & $<0.01$ \\
\hline Brier $\times C b \quad 1084$ & $\mathrm{~F}_{3} \mathrm{f}$ & 14 & 193 & 0 & 0 & $7: 8: 1$ & $<0.01$ \\
\hline Hudson $\times$ Turk & $\mathrm{F}_{3} \mathrm{f}$ & 14 & 44 & 0 & 0 & $7: 8: 1$ & $<0.01$ \\
\hline Modoc $\times$ Turk & $F_{3} f$ & 14 & 189 & 0 & 0 & $7: 8: 1$ & $<0.01$ \\
\hline Modoc $\times$ Brier & $\mathrm{F}_{3} \mathrm{f}$ & 14 & 193 & 0 & 0 & $7: 8: 1$ & $<0.01$ \\
\hline Modoc $\times C b \quad 1084$ & $\mathrm{~F}_{3} \mathrm{f}$ & 14 & 194 & 0 & 0 & $7: 8: 1$ & $<0.01$ \\
\hline Dea $\times C b 1084$ & $F_{2}$ & 14 & 615 & - & 0 & $15: 1$ & $<0.01$ \\
\hline
\end{tabular}

* $\mathrm{F}_{3} \mathrm{f}$ refers to $\mathrm{F}_{3}$ families. $\mathrm{F}_{3} \mathrm{~s}$ to the total number of plants within segregating $\mathrm{F}_{3}$ families only.

allowing a type 2 reaction to develop slowly when in the heterozygous condition. Confirmation of this hypothesis is available from tests on four $F_{1}$ hybrids from the same cross, which were completely resistant 14 days after inoculation, but developed type 2 symptoms within 28 days after inoculation.

The segregation of the progeny from crosses involving Turk, Atlas 46, Brier, Hudson, Dea and Modoc in response to inoculation with isolate 1394 are presented in table 3 . When crossed with the susceptible varieties 
Proctor or Maris Otter, all these resistant varieties gave $\mathrm{F}_{2}$ or $\mathrm{F}_{3}$ segregations compatible with the hypothesis that resistance in each variety was conferred by a single dominant gene which was fully effective at both 14 and 28 days after inoculation.

Crosses were also made between $C b 1084$ and Brier, Dea and Modoc; between Turk and Atlas 46, Brier, Hudson and Modoc; and between Brier and Modoc. In each case, all $\mathrm{F}_{2}$ plants or $\mathrm{F}_{3}$ families tested were completely resistant (see table 3).

The genetic control of resistance in Osiris was first examined in an $F_{3}$ population from the cross Osiris $\times$ Proctor, tested with isolate 1394 . When

TABLE 4

The reaction of $F_{2}$ and $F_{3}$ progeny from crosses involving Osiris to isolates 1394 and 1436 of $\mathrm{R}$. secalis

\begin{tabular}{|c|c|c|c|c|c|c|c|}
\hline \multirow[b]{2}{*}{ Cross } & \multirow[b]{2}{*}{ Generation } & \multirow{2}{*}{$\begin{array}{c}\text { Days } \\
\text { after } \\
\text { inoculation }\end{array}$} & \multicolumn{3}{|c|}{$\begin{array}{l}\text { Observed } \\
\text { frequency }\end{array}$} & \multirow{2}{*}{$\begin{array}{l}\text { Expected } \\
\text { ratio }\end{array}$} & \multirow[b]{2}{*}{ Probability } \\
\hline & & & Res. & Seg. & Sus. & & \\
\hline Osiris $\times$ Proctor* & $\mathrm{F}_{3} \mathrm{f}$ & 14 & 48 & 111 & 52 & $1: 2: 1$ & $0 \cdot 5-0 \cdot 7$ \\
\hline Osiris $\times$ Proctor* & $\mathrm{F}_{3} \mathrm{~s}$ & 14 & 1631 & - & 546 & $3: 1$ & $0.9-0.95$ \\
\hline Osiris $\times$ Proctor & $\mathrm{F}_{3} \mathrm{f}$ & 28 & 14 & 113 & 84 & $1: 8: 7$ & $0 \cdot 5-0 \cdot 7$ \\
\hline Osiris $\times$ Proctor* & $\mathrm{F}_{3} \mathrm{~s} \dagger$ & 28 & 259 & 一 & 76 & $3: 1$ & $0 \cdot 3-0 \cdot 5$ \\
\hline Osiris $\times$ Proctor & $\mathrm{F}_{2}$ & 14 & 67 & - & 20 & $3: 1$ & $0 \cdot 5-0 \cdot 7$ \\
\hline Osiris $\times$ Proctor & $\mathrm{F}_{2}$ & 28 & 48 & - & 39 & $9: 7$ & $0 \cdot 7-0.8$ \\
\hline Osiris $\times$ Turk* & $F_{3} f$ & 14 & 243 & 0 & 0 & $7: 8: 1$ & $<0.01$ \\
\hline Osiris $\times$ Brier* & $\mathrm{F}_{3} \mathrm{f}$ & 14 & 197 & 0 & 0 & $7: 8: 1$ & $<0.01$ \\
\hline Osiris $\times$ Atlas $46^{*}$ & $\mathrm{~F}_{3} \mathrm{f}$ & 14 & 178 & 1 & 0 & $7: 8: 1$ & $<0.01$ \\
\hline Osiris $\times$ Atlas $46^{*}$ & $\mathrm{~F}_{3} \mathrm{~s}$ & 14 & 19 & - & 6 & $3: 1$ & $0.9-0.95$ \\
\hline Osiris $\times$ Turk* & $\mathrm{F}_{2}$ & 28 & 97 & - & 7 & $15: 1$ & $0.8-0.9$ \\
\hline Osiris $\times$ Modoc & $\mathrm{F}_{2}$ & 28 & 137 & - & 9 & $15: 1$ & $<0.95$ \\
\hline Osiris $\times$ Modoc* & $\mathrm{F}_{3} \mathrm{f}$ & 14 & 193 & 0 & 0 & $7: 8: 1$ & $<0.01$ \\
\hline
\end{tabular}

assessed 14 days after inoculation, the segregation of this material gave a good fit to a ratio of 1 resistant : 2 segregating : 1 susceptible families, with a ratio of 3 resistant : 1 susceptible plants in the segregating families (table 4). Thus, at this stage, resistance was controlled by a single dominant gene. However, a re-assessment 28 days after inoculation showed that a number of plants which were resistant after 14 days had developed lesions; considering these as susceptible (although they varied in reaction from type 2 to type 3 ), the segregation then fitted a ratio of 1 resistant : 8 segregating : 7 susceptible families. Within the families resistant at 14 but segregating at 28 days after inoculation, the final ratio of resistant to susceptible plants did not differ significantly from $3: 1$. Seven $F_{1}$ hybrids were also tested, and were completely resistant at both assessment times.

These results suggest that the resistance of Osiris is controlled by two complementary genes. The first of these is incompletely dominant, being fully effective 14 days after inoculation, but subsequently permitting a type 2 reaction to develop when in the homozygous condition, and a type 3 reaction when heterozygous. The second gene is completely dominant, but operates only in conjunction with the first. Thus its presence was not 
apparent at the first assessment, but it prevented the later development of symptoms, when either homozygous or heterozygous.

Some $\mathrm{F}_{2}$ plants from the cross Osiris $\times$ Proctor were tested simultaneously against isolates 1394 and 1436, by inoculation of the second leaf with one and the third leaf with the other isolate. The segregations obtained with both isolates at 14 and 28 days after inoculation supported the conclusions drawn from the $\mathrm{F}_{3}$ data, and each plant showed identical reaction to both isolates. Thus if two different gene pairs conferred resistance to the two isolates, they would have to be less than 3.3 cross-over units apart in each case.

TABLe 5

The reaction of $F_{2}$ and $F_{3}$ progeny from crosses involving La Mesita, C.I. 3515, C.I. 8256 and Gembloux 14 to isolate 1394 of R. secalis

\begin{tabular}{|c|c|c|c|c|c|c|c|}
\hline \multirow[b]{2}{*}{ Cross } & \multirow[b]{2}{*}{ Generation } & \multirow{2}{*}{$\begin{array}{c}\text { Days } \\
\text { after } \\
\text { inoculation }\end{array}$} & \multicolumn{3}{|c|}{$\begin{array}{l}\text { Observed } \\
\text { frequency }\end{array}$} & \multirow{2}{*}{$\begin{array}{l}\text { Expected } \\
\text { ratio }\end{array}$} & \multirow[b]{2}{*}{ Probability } \\
\hline & & & Res. & Seg. & Sus. & & \\
\hline La Mesita $\times$ Proctor & $\mathrm{F}_{2}$ & 14 & 139 & - & 58 & $3: 1$ & $0 \cdot 1-0 \cdot 2$ \\
\hline La Mesita $\times$ Proctor & $\mathrm{F}_{2}$ & 28 & 115 & - & 82 & $9: 7$ & $0 \cdot 5-0 \cdot 7$ \\
\hline C.I. $3515 \times$ Proctor & $\mathrm{F}_{2}$ & 14 & 262 & - & 97 & $3: 1$ & $0 \cdot 3-0 \cdot 5$ \\
\hline C.I. $3515 \times$ Proctor & $\mathrm{F}_{2}$ & 28 & 84 & - & 72 & $9: 7$ & $0 \cdot 5-0 \cdot 7$ \\
\hline C.I. $8256 \times$ Proctor & $\mathrm{F}_{2}$ & 14 & 350 & - & 120 & $3: 1$ & $0 \cdot 7-0 \cdot 8$ \\
\hline C.I. $8256 \times$ Proctor & $\mathrm{F}_{2}$ & 28 & 78 & - & 64 & $9: 7$ & $0 \cdot 7-0 \cdot 8$ \\
\hline Gembloux $14 \times$ Proctor & $\mathrm{F}_{2}$ & 14 & 254 & - & 84 & $3: 1$ & $0 \cdot 9-0 \cdot 95$ \\
\hline Gembloux $14 \times$ Proctor & $\mathrm{F}_{2}$ & 28 & 44 & - & 36 & $9: 7$ & $0 \cdot 8-0 \cdot 9$ \\
\hline La Mesita $\times$ Osiris & $\mathrm{F}_{3} \mathrm{f}$ & $14 \& 28$ & 197 & 0 & 0 & $7: 8: 1$ & $<0.01$ \\
\hline C.I. $3515 \times$ Osiris & $\mathrm{F}_{3} \mathrm{f}$ & $14 \& 28$ & 171 & 0 & 0 & $7: 8: 1$ & $<0.01$ \\
\hline C.I. $8256 \times$ Osiris & $\mathrm{F}_{3} \mathrm{f}$ & $14 \& 28$ & 194 & 0 & 0 & $7: 8: 1$ & $<0 \cdot 01$ \\
\hline Gembloux $14 \times$ Osiris & $\mathrm{F}_{3} \mathrm{f}$ & $14 \& 28$ & 25 & 0 & 0 & $7: 8: 1$ & $<0.01$ \\
\hline
\end{tabular}

$\mathrm{F}_{3}$ populations from the crosses Osiris $\times$ Turk, Osiris $\times$ Brier and Osiris $\times$ Modoc were all completely resistant 14 days after inoculation with isolate 1394 , but in the cross Osiris $\times$ Atlas 46 , one family out of 179 was found to be segregating in a ratio of 3 resistant : 1 susceptible plants (see table 4 ). Thus the gene in Osiris which is active up to 14 days after inoculation is either closely linked to that in Atlas 46 , and the segregating family arose as a result of genetic recombination, or the genes are allelic, and the segregating family arose as a result of an outcross to a susceptible variety; this was one of the crosses which were not protected at anthesis in the $F_{1}$ generation. $F_{2}$ progeny from crosses between Osiris and Turk and Modoc were assessed 28 days after inoculation, when a segregation not significantly different from $15: 1$ indicated that neither Turk nor Modoc carried the complementary gene present in Osiris.

The $\mathrm{F}_{2}$ progeny from crosses of La Mesita, C.I. 3515, C.I. 8256 and Gembloux 14 with Proctor all segregated in ratios not significantly different from the ratios expected if resistance in these varieties was controlled by a gene system similar to that found in Osiris (see table 5). Crosses between these varieties and Osiris all produced $\mathrm{F}_{3}$ populations which were completely resistant at both 14 and 28 days after inoculation, indicating that the gene pairs in these varieties were either identical, allelic or closely linked to the pair in Osiris.

When inoculated with isolate 1394 , the segregation of $F_{2}$ progeny from 
the cross $\mathcal{F} e t \times$ Proctor indicated that resistance in $\mathcal{F} e t$ was controlled by two complementary recessive genes (table 6 ). The $\mathrm{F}_{3}$ progeny from crosses of Jet with Turk, Osiris, Brier and Modoc were all completely resistant 14 days after inoculation, indicating that one of the recessive genes in Fet is allelic or closely linked to the dominant genes in these varieties, which also carry the other recessive gene.

\section{TABLE 6}

The reaction of $F_{2}$ and $F_{3}$ progeny from crosses involving fet to isolate 1394 of $\mathrm{R}$. secalis

\begin{tabular}{|c|c|c|c|c|c|c|c|}
\hline \multirow[b]{2}{*}{ Cross } & \multirow[b]{2}{*}{ Generation } & \multirow{2}{*}{$\begin{array}{c}\text { Days } \\
\text { after } \\
\text { inoculation }\end{array}$} & \multicolumn{3}{|c|}{$\begin{array}{l}\text { Observed } \\
\text { frequency }\end{array}$} & \multirow{2}{*}{$\begin{array}{l}\text { Expected } \\
\text { ratio }\end{array}$} & \multirow[b]{2}{*}{ Probability } \\
\hline & & & Res. & Seg. & Sus. & & \\
\hline Jet $\times$ Proctor & $\mathrm{F}_{2}$ & 14 & 19 & - & 289 & $1: 15$ & $<0.95$ \\
\hline Jet $\times$ Turk & $F_{3} f$ & 14 & 93 & 0 & 0 & $19: 38: 7$ & $<0.01$ \\
\hline Jet $\times$ Osiris & $F_{3} f$ & 14 & 91 & 0 & 0 & $19: 38: 7$ & $<0.01$ \\
\hline fet $\times$ Brier & $\mathrm{F}_{3} \mathrm{f}$ & 14 & 94 & 0 & 0 & $19: 38: 7$ & $<0.01$ \\
\hline Fet $\times$ Modoc & $\mathrm{F}_{3} \mathrm{f}$ & 14 & 98 & 0 & 0 & $19: 38: 7$ & $<0.01$ \\
\hline
\end{tabular}

The resistance of Nigrinudum to isolate 1394 is controlled by a single recessive gene, as shown by the segregation of $\mathrm{F}_{2}$ plants from a cross with Proctor (table 7). The segregation of $\mathrm{F}_{2}$ or $\mathrm{F}_{3}$ progeny from crosses with

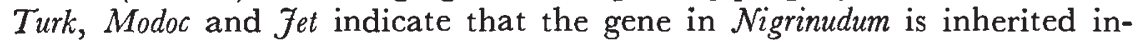
dependently of the genes in these varieties.

\section{TABLE 7}

The reaction of $F_{2}$ and $F_{3}$ progeny from crosses involving $\mathcal{N i g r i n u d u m}$, C.I. 4364 and C.I. 4368 to isolate 1394 of $\mathrm{R}$. secalis

\begin{tabular}{|c|c|c|c|c|c|c|c|}
\hline \multirow[b]{2}{*}{ Cross } & \multirow[b]{2}{*}{$\begin{array}{c}\text { Genera- } \\
\text { tion }\end{array}$} & \multirow{2}{*}{$\begin{array}{c}\text { Days } \\
\text { after } \\
\text { inocula- } \\
\text { tion }\end{array}$} & \multicolumn{3}{|c|}{$\begin{array}{l}\text { Observed } \\
\text { frequency }\end{array}$} & \multirow[b]{2}{*}{$\begin{array}{l}\text { Expected } \\
\text { ratio }\end{array}$} & \multirow[b]{2}{*}{ Probability } \\
\hline & & & Res. & Seg. & Sus. & & \\
\hline Nigrinudum $\times$ Proctor & $\mathrm{F}_{2}$ & 14 & 55 & - & 139 & $1: 3$ & $0 \cdot 2-0 \cdot 3$ \\
\hline Nigrinudum $\times$ Turk & $\mathrm{F}_{2}$ & 14 & 127 & - & 33 & $13: 3$ & $0.5-0.7$ \\
\hline Nigrinudum $\times$ Modoc & $\mathrm{F}_{2}$ & 14 & 91 & - & 27 & $13: 3$ & $0 \cdot 2-0 \cdot 3$ \\
\hline Nigrinudum $\times$ Jet & $F_{2}^{2}$ & 14 & 44 & - & 123 & $19: 45$ & $0.3-0.5$ \\
\hline Nigrinudum $\times \mathcal{F} e t$ & $F_{8} f$ & 14 & 13 & 30 & 5 & $19: 38: 7$ & $0.9-0.95$ \\
\hline C.I. $4368 \times$ Proctor & $F_{2}$ & 14 & 79 & - & 219 & $1: 3$ & $0.5-0.7$ \\
\hline C.I. $4368 \times$ Brier & $\mathrm{F}_{2}$ & 14 & 136 & - & 28 & $13: 3$ & $0.5-0.7$ \\
\hline C.I. $4368 \times$ Jet & $\mathrm{F}_{2}$ & 14 & 46 & - & 89 & $19: 45$ & $0 \cdot 2-0 \cdot 3$ \\
\hline C.I. $4368 \times$ Nigrinudum & $F_{3} \mathrm{f}$ & 14 & 24 & 34 & 6 & $7: 8: 1$ & $0 \cdot 3-05$ \\
\hline C.I. $4364 \times$ Proctor & $\mathrm{F}_{2}$ & 14 & 71 & - & 223 & $1: 3$ & 0.7 .08 \\
\hline C.I. $4364 \times$ C.I. 4368 & $\mathrm{~F}_{3} \mathrm{f}$ & 14 & 42 & 0 & 0 & $7: 8: 1$ & $<0.01$ \\
\hline
\end{tabular}

The results obtained with $\mathrm{F}_{2}$ progeny from crosses with Proctor indicated that C.I. 4364 and C.I.4368 each contained a single recessive gene for resistance. An intercross between the two varieties produced an $F_{3}$ population which was completely resistant, showing that the genes were at the same locus (table 7). However, this recessive gene was independent of that found in Nigrinudum, since the $\mathrm{F}_{3}$ population from the cross C.I. $4368 \times$ Nigrinudum segregated to fit a ratio of 7 resistant $: 8$ segregating : 1 susceptible families. 
Table 8 contains the results from crosses made to determine the location of the resistance genes in Turk and Osiris. The Turk $\times$ "uzu" and Osiris $\times$ "streaked" crosses, tested as $F_{2}$ seedlings in the glasshouse for both the genetic marker and disease reaction, indicated linkage distances of $8.3 \pm 1.7$ cross-over units between the locus of the resistance gene and $u z$ and $7.7 \pm 1.5$ units between the resistance gene and st. The Osiris $\times$ "uzu " cross was observed in the field as $F_{2}$ plants for the " uzu " character, and the harvested $\mathrm{F}_{3}$ seed was tested in the glasshouse for resistance 14 days after inoculation; a linkage value of $12 \cdot 1 \pm 3 \cdot 8$ cross-over units was obtained between the gene for resistance and $u z$.

\section{TABLE 8}

The reactions of $F_{2}$ progeny from crosses between the resistant varieties Turk and Osiris and stocks containing the genes $\mathrm{uz}, \mathrm{st}$ and the interchange $T 2-3 d$

(a) Marker genes

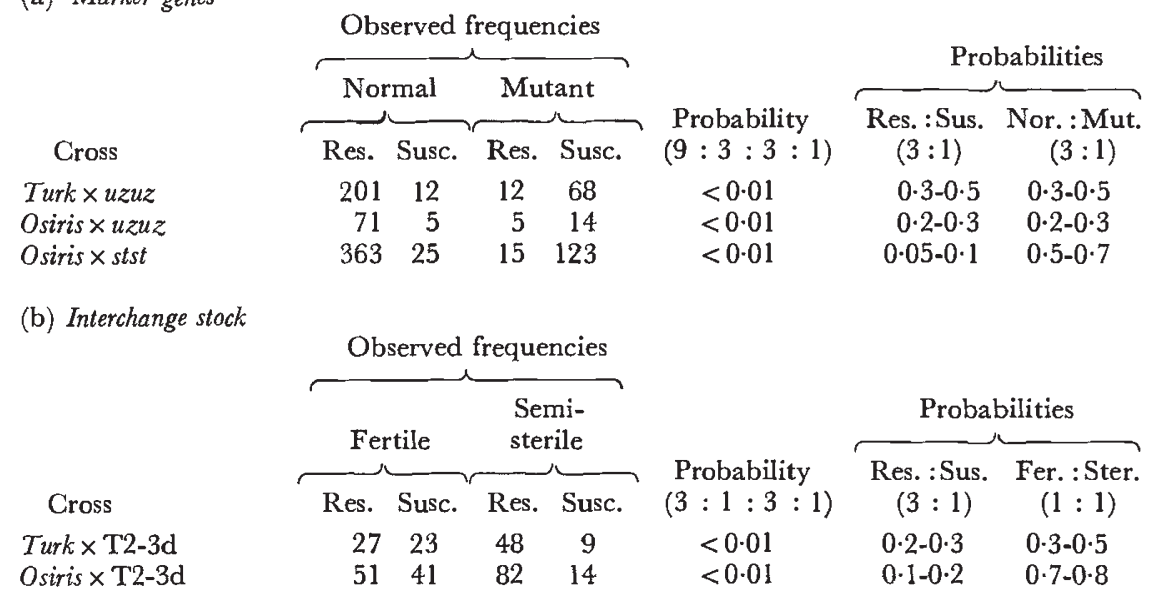

$F_{2}$ plants from the crosses involving the chromosome interchange stock T2-3d were observed in the field for semi-sterility; the Turk $\times$ T2-3d progeny were also tested for resistance in the field, whilst the Osiris $\times$ T2-3d progeny were tested in the glasshouse for resistance as $\mathrm{F}_{3}$ seedlings. The break-point in T2-3d was found to be linked at $13.9 \pm 5 \cdot 1$ units from the resistance gene in Turk, and 13.4 \pm 3.8 units from the gene in Osiris whose resistance is expressed 14 days after inoculation.

\section{Discussron}

The results obtained from crosses involving Turk, Atlas 46, Brier, Modoc and $C b 1084$ suggest that the resistance genes in these varieties are all situated at the same locus, although the same results could be obtained if there were separate loci up to 1.7 cross-over units apart. It is also possible that $H u d s o n$ and Dea contain genes at this locus, but the evidence for these varieties is less conclusive, since in the Hudson $\times$ Turk and Dea $\times$ Cb1084 (Wisconsin Winter $\times$ Glabron) crosses, recombination rates of up to 6.5 and 13.8 per cent. respectively could have passed undetected in the populations studied.

The gene in Modoc can be differentiated from the others at the same 
locus by its ineffectiveness against isolate 1435, and that in $C b 1084$ by its incomplete dominance. The other five varieties, Turk, Atlas 46, Brier, Hudson and Dea, all exhibit identical patterns in both inheritance of resistance and reaction to the test isolates, which suggests that the resistance genes in these varieties are identical.

In the case of Atlas 46 , this suggestion is further substantiated by its ancestry; the resistance was derived from Turk through a back-crossing programme (Schaller, 1951). Dyck and Schaller (1961a) and Starling et al. (1969) found two dominant genes in Atlas 46, only one of which was also found in Turk, the other being found in Atlas. This resistance gene was not detected in our studies since Atlas was susceptible to the three isolates of $R$. secalis tested. Frecha (1967) was also unable to identify more than one resistance gene in Atlas 46.

A single dominant gene for resistance, $R h$, was found in Brier by Bryner (1957). Dyck and Schaller (1961a) also found a single dominant gene in Brier, which was identical, allelic or closely linked to one of two dominant genes in Turk. The genes in Turk were designated $R h 3$ and $R h 5, R h 3$ conferring resistance indistinguishable from that of Brier and Hudson in their tests with four physiologic races of $R$. secalis. The location of $R h 3$, relative to certain genetic marker loci (Dyck and Schaller, 1961b), was compatible with the relationships established for the gene found in Turk in this study.

Although Riddle and Briggs (1950) discovered more than one resistance gene in Turk, the additional gene was clearly not effective against isolate 1394, since no evidence of its presence was found in our tests. Wells and Skoropad (1963), Baker and Larter (1963) and Evans (1969) were likewise able to detect only one resistance gene in Turk. Starling et al. (1971) detected only one gene in Turk, which was identical, allelic or closely linked to the genes found in Brier and Hudson.

All this work supports our suggestion that the resistance genes we detected in Turk, Atlas 46, Brier and Hudson are identical. (Dea has not been studied genetically by other workers, but Williams (1969) was unable to differentiate Dea from Turk, Atlas 46, or Brier in a physiologic race survey in Britain.) However, physiologic race studies carried out by Schein (1958) do not support this suggestion. He used these varieties in a differential set, and found they gave different reactions to some of the seven U.S. races of $R$. secalis identified. However, Schein's tests were carried out under conditions which induced symptoms dissimilar to those obtained here and by Dyck and Schaller (1961a). Therefore, it is possible that the expression of resistance conferred by these genes can be influenced by the environment, the method of handling, or the genetic background in which the genes are located.

The resistance of Modoc, which we consider to be controlled by an allele of the gene in Turk, Atlas 46, Brier and Hudson, was also differentiated from these varieties in physiologic race tests by Schein (1958) and Dyck and Schaller (1961a). However, Dyck and Schaller considered the gene in Modoc not to be allelic, but closely linked to that in Turk, on the basis of crosses involving Modoc, Atlas 46 and La Mesita (see below). The recessive gene discovered by Riddle and Briggs (1950) in Modoc was not identified here or by Dyck and Schaller.

Cb 1084 has not previously been studied genetically, but the inheritance of resistance in this variety was similar to that described by Baker and Larter 
(1963) for the gene Rh9 in Kitchin and C.I. 668. These workers did not test Rh9 for allelism with other known dominant genes.

The inheritance of resistance in La Mesita, Gembloux 14, C.I. 3515 and C.I. 8256 was found to be identical to that in Osiris. In crosses between Osiris and these varieties, all the $\mathrm{F}_{3}$ progeny were completely resistant, which limits the maximum possible recombination level between two gene pairs to less than about 1.9 per cent. Since all five varieties were resistant to the three test isolates, it is highly probable that they all contain the same pair of complementary genes.

Schein (1958) reported La Mesita to be susceptible to race U.S.-6, whereas Gembloux 14, C.I. 3515 and C.I. 8256 were resistant to this race (Schein, 1960), and Wells and Skoropad (1963) used an isolate which was pathogenic on La Mesita but not on Osiris. These apparent reaction differences may be attributable to differences in genetic background between varieties, rather than to specific major gene differences. In our experience, La Mesita develops disease symptoms in field nurseries, whereas C.I. 8256 does not. However, when the resistance genes from C.I. 8256 were back-crossed into an adapted genotype, these plants also exhibited disease symptoms in the field. Riddle and Briggs (1950) reported that susceptibility in adult and seedling plants of La Mesita is associated with senescence of the leaves.

When Osiris was crossed with Turk, Brier and Modoc, all the $\mathbf{F}_{\mathbf{3}}$ families were completely resistant 14 days after inoculation, suggesting that the effective gene in Osiris is allelic to the genes in these other varieties. However, the cross Osiris $\times$ Atlas 46 produced one segregating family out of 179 . This we considered to be the result of an outcross to a susceptible variety, rather than a recombinant, since the $F_{1}$ hybrids from this cross were not protected at anthesis. The frequency of natural outcrossing in normally self-fertilising barley genotypes has been variously estimated as less than $0 \cdot 15$ per cent. (Stevenson, 1928; Robertson and Deeming, 1931) or up to 2 per cent. (Jain and Allard, 1960).

Dyck and Schaller (1961a) obtained three segregating families in an $\mathbf{F}_{\mathbf{3}}$ population of 317 from the cross Atlas $46 \times$ La Mesita, and considered this too many to be attributable to outcrossing. On the basis of this and other crosses and physiologic race tests, they concluded that La Mesita and Osiris contained a resistance gene, $R h 4$, located $1 \cdot 0 \pm 0.78$ crossover units from the gene in Atlas 46 and Turk, and that Modoc contained an allele of this gene, which they designated $R h 4^{2}$.

Assuming that it was the same genes which were studied in these varieties by Dyck and Schaller and ourselves, it is important from the view of plant breeding to determine which of the two hypotheses is correct, since nonallelic genes can be coupled in a homozygous variety, whereas allelic genes cannot be combined. If our results are interpreted in accordance with Dyck and Schaller's hypothesis, the data from several crosses can be combined, giving a " recombination "value of about $0 \cdot 1$ per cent. which is well outside the standard error of Dyck and Schaller's estimate. Thus we consider that the genes for resistance in Turk, Atlas 46, Brier (Hudson, Dea), Wisconsin Winter $\times$ Glabron, Modoc, Osiris, La Mesita (Gembloux 14), C.I. 3515 and C.I. 8256 are located at the same locus.

The gene we detected in Osiris which is complementary to the one effective 14 days after inoculation has not been previously reported, presumably because its effect is not apparent until well after the normal times of assess- 
ment, when seedling material being subjected to glasshouse tests would generally have been discarded. Many workers have considered the gene in Osiris and allied varieties to be identical to that in Turk and Atlas 46 (Riddle and Briggs, 1950; Wells and Skoropad, 1963; Frecha, 1967), but this conclusion was always based on the results of tests using only one isolate of $R$. secalis.

Jet has previously been reported to contain two complementary recessive genes, designated $r h 6$ and $r h 7$ (Baker and Larter, 1963), but these were tested for allelism only with the recessive gene in Nigrinudum. In this study, it was confirmed that resistance was controlled by two complementary recessive genes, but one of these was shown to be situated at the locus carrying the dominant genes in Turk, Brier, Modoc and Osiris, whilst the other gene was also present in these varieties, but not in Proctor or Nigrinudum (nor in Montcalm, the susceptible variety used by Baker and Larter). In varieties other than $\mathcal{F e t}$, this complementary gene appears to be neutral, since its effect was not noted in other crosses involving Turk, Brier, Modoc or Osiris. It is unrelated to the complementary gene in Osiris, which has been shown to be absent from Turk and Modoc.

The recessive gene isolated from $\mathcal{N}$ igrinudum is probably that designated rh8 by Wells and Skoropad (1963), and, as with these authors, our results show this gene to be inherited independently of all other genes. The recessive gene found in C.I. 4364 and C.I. 4368 has not been previously reported.

The results reported here indicate that the designations previously applied to certain genes are not completely valid. Since the gene designated Rh3 in Turk and Atlas 46 by Dyck and Schaller (1961a) is probably identical to the gene designated $R h$ in Brier by Bryner (1957), the latter symbol takes precedence. The same gene is also probably present in Hudson and Dea. It has also been shown that the $R h 4$ locus of Dyck and Schaller is not separate from the $R h$ locus, so that the symbol $R h^{4}$ is more suitable for the gene active 14 days after inoculation in Osiris, La Mesita, Gembloux 14, C.I. 3515 and C.I. 8256 . The gene complementary to $R h^{4}$ has not previously been reported, and the symbol $R h 10$ is suggested for it. Since the gene in Modoc has also been shown to be at the $R h$ locus, Dyck and Schaller's symbol $R h 4^{2}$ should be amended to $R h^{2}$. Also at this locus is the dominant gene in $C b 1084$, for which the symbol $R h^{3}$ is suggested.

One of the complementary recessive genes in $7 e t$ has also been shown to be situated at the $R h$ locus. Baker and Larter's (1963) designation of $r h 7$ could therefore be amended to $r h^{5}$, whilst $r h 6$ is retained for the other gene, which is also present in Turk, Brier, Modoc and Osiris; consequently the genotypes of these varieties should be amended to include this gene. The designation $r h 8$ for the recessive gene in Nigrinudum should be retained, and the symbol $r h 11$ is suggested for the recessive gene in C.I. 4364 and C.I. 4368 . These changes in nomenclature for the genes for resistance to $R$. secalis are summarised in table 9.

The results of our studies show that there are five alleles at the $R h$ locus; two are dominant $\left(R h\right.$ and $\left.R h^{2}\right)$, two are incompletely dominant $\left(R h^{3}\right.$ and $\left.R h^{4}\right)$ and one is recessive $\left(r h^{5}\right)$. The phenomenon of multiple allelism has been reported in several host-pathogen systems, e.g. at the Mla locus conditioning mildew resistance in barley (Moseman, 1966). However, the $R p 1$ locus conditioning rust resistance in maize, once believed to have 13 alleles, has now been resolved into at least five separate loci with less than 0.4 per 
cent. recombination between them (Saxena and Hooker, 1964, 1967). The detection of linkages of this order in barley would require the testing of at least $760 \mathrm{~F}_{\mathbf{3}}$ families from each cross.

Nevertheless, further investigations of this locus may prove valuable, since pseudoallelism would enable breeders to intercross resistant varieties and obtain new combinations of resistance genes, effective against wide spectra of pathogenicity.

\section{TABLE 9}

Suggested revision of the symbols allocated to barley genes conferring resistance to $\mathrm{R}$. secalis, and allocation of symbols to new genes identified

\begin{tabular}{|c|c|c|c|}
\hline \multirow[b]{2}{*}{ Variety } & \multicolumn{3}{|c|}{ Genetic Constitution } \\
\hline & Previous & & Amended \\
\hline Turk & Rh3Rh3Rh5Rh5 & $(b)$ & RhRh(Rh5Rh5)rh6rh6 \\
\hline Atlas 46 & Rh2Rh2Rh3Rh3 & (b) & RhRh(Rh2Rh2) \\
\hline Brier & $\mathrm{RhRh}$ & (a) & RhRhrh6rh6 \\
\hline Hudson & - & & RhRh \\
\hline Dea & - & & RhRh \\
\hline Osiris & Rh4Rh4 & $(b)$ & $\mathrm{Rh}^{4} \mathrm{Rh}^{4} \mathrm{rh} 6 \mathrm{rh} 6 \mathrm{Rh} 10 \mathrm{Rh} 10$ \\
\hline La Mesita & Rh4Rh4 & (b) & $\mathrm{Rh}^{4} \mathrm{Rh}^{4} \mathrm{Rh} 10 \mathrm{Rh} 10$ \\
\hline C.I. 3515 & Rh3Rh3 & $(c)$ & $\mathrm{Rh}^{4} \mathrm{Rh}^{4}{ }^{4} \mathrm{Rh} 10 \mathrm{Rh} 10$ \\
\hline C.I. 8256 & Rh3Rh3 & (c) & $\mathrm{Rh}^{4} \mathrm{Rh}^{4} \mathrm{Rh} 10 \mathrm{Rh} 10$ \\
\hline Gembloux 14 & 一 & & $\mathrm{Rh}^{4} \mathrm{Rh}^{4} \mathrm{Rh} 10 \mathrm{Rh} 10$ \\
\hline Wisc. Winter $\times$ Glabron & - & & $\mathrm{Rh}^{3} \mathrm{Rh}^{3}$ \\
\hline Modoc & $\mathrm{Rh} 4^{2} \mathrm{Rh} 4^{2}$ & (b) & $\mathrm{Rh}^{2} \mathrm{Rh}^{2} \mathrm{rh} 6 \mathrm{rh} 6$ \\
\hline Fet & rh6rh6rh7rh7 & $(d)$ & $\mathrm{rh}^{5} \mathrm{rh}^{5} \mathrm{rh} 6 \mathrm{rh} 6$ \\
\hline Nigrinudum & rh8rh8 & $(c)$ & rh8rh8 \\
\hline C.I. 4364 & - & & rhllrhl \\
\hline C.I. 4368 & - & & rhllrhll \\
\hline
\end{tabular}

References: (a) Bryner, 1957. (b) Dyck and Schaller, 1961a. (c) Wells and Skoropad, 1963. (d) Baker and Larter, 1963.

The $\mathrm{Rh}$ genes referred to in parentheses signify genes identified by other workers but not detected in this study.

\section{Summary}

1. Of the 18 barley varieties studied, 16 exhibited resistance to $R$. secalis controlled by five single genes and two pairs of complementary genes.

2. The dominance of these genes and their effectiveness against three isolates of the pathogen was established.

3. Five alleles or pseudoalleles were found at one locus on chromosome 3, whilst the remainder were inherited independently of this locus, and possibly of each other.

4. New or revised symbols are proposed for the designation of some of the resistance genes identified.

Acknowledgments.-We wish to thank Professor P. T. Thomas, C.B.E., Director of the Welsh Plant Breeding Station, for his interest in this work, and the Ministry of Agriculture, Fisheries and Food for a Postgraduate Studentship which enabled one of us (R. M. H.) to carry out these studies. Technical assistance from Mr D. L. Jones and Mrs D. A. Ralphs is also gratefully acknowledged. 


\section{REFERENGES}

BAKER, R. J., AND LARTER, E. 1963. Inheritance of scald resistance in barley. Can. F. Genet. Cytol., 5, 445-449.

BRYNER, c. s. 1957. Inheritance of scald resistance in barley. Ph.D. Thesis, Pa. Sta. Univ. (Diss. Abstr., 17, 2752).

DYCK, P. L., AND SCHALleR, C. W. 1961a. Inheritance in barley of resistance to several physiologic races of the scald fungus. Can. F. Genet. Cytol., 3, 153-164.

DYCK, P. L., AND SCHALLER, C. w. 1961 b. Association of two genes for scald resistance with a specific barley chromosome. Can. 7. Genet. Cytol., 3, 165-169.

EVANS, R. L. 1969. Studies on the leaf blotch of barley (Rhynchosporium secalis). Ph.D Thesis, Univ. Wales.

Fisher, R. A., AND yates, F. 1963. Statistical Tables for Biological, Medical and Agricultural Research. Oliver and Boyd, Edinburgh.

FRECHA, J. H. 1967. Inheritance of resistance to Rhynchosporium secalis in barley. Bol. Genet. Inst. Fitotec. Castelar, 4, 5-13.

hanson, w. D. 1959. Minimum family sizes for planning genetic experiments. Agron. $\mathcal{J}$., 51, 711-715.

JAIN, s. K., AND ALlARD, R. w. 1960. Population studies in predominantly self-pollinated species. I. Evidence for heterozygote advantage in a closed population of barley. Proc. natn. Acad. Sci. U.S.A., 46, $1371-1377$.

JOACHIM, GERTRUDE s. 1947. The product method of calculating linkage from $F_{2}$ data involving semi-sterility, and its application to barley translocation. Genetics, 32, 580-591.

MACKIE, w. w. 1929. Inheritance of resistance to barley scald. (Abstr.) Phytopathology, 19, 1141 .

moseman, J. G. 1966. The genetics of powdery mildews. A. Rev. Phytopath., 4, 269-290.

RIDDLE, O. C., AND BRIGGS, F. N. 1950. Inheritance of resistance to scald in barley. Hilgardia, 20, 19-27.

ROBERTSON, D. w. 1960. Summary of linkage studies in barley, 1956-60. Fourth Barley Improvement Conf., North Dakota Agr. Coll. (Mimeo. Abstr.), 25-31.

ROBERTSON, D. W., DEeming, G. W., 1931. Natural crossing in barley at Fort Collins, Colorado. Agron. 7., 23, 402-406.

SARASOLA, J. A., AND CAMPI, M. D. 1947. Reaccion de algunas cebedas con respecto a Rhynchosporium secalis en Argentine. Rev. Invest. agric., B. Aires, 1, 243-260.

SAXENA, K. M. S., AND HOOKER, A. L. 1964. The nature of locus $R p 1$ conditioning resistance to rust in corn. (Abstr.) Phytopathology, 54, 905.

SAXENA, K. M. S., AND HOOKER, A. L. 1967. Pseudo allelism at the locus $R p 1$ for resistance to rust in maize. (Abstr.) Phytopathology, 57, 828.

schaller, c. w. 1951. The effect of mildew and scald infection on yield and quality of barley. Agron 7., 43, 183-188.

sCHeIn, R. D. 1958. Pathogenic specialisation in Rhynchosporium secalis. Phytopathology, 48, $477-480$.

SGHEIN, R. D. 1960. Physiologic and pathogenic specialisation of Rhynchosporium secalis. Bull. Pa. agric. Exp. Sta., 664.

SCHein, R. D., AND Kerelo, J. W. 1956. Culturing Rhynchosporium secalis. Pl. Dis. Reptr., 40, 814-815.

STARLING, T. M., ROANE, C. W. AND KUO-RUEY CHI. 1971. Inheritance of reaction to Rhynchosporium secalis in winter barley. Proc. Second Inter. Barley Genet. Symposium, Pullman, Washington, 1969, 513-519.

stevenson, F. J. 1928. Natural crossing in barley. Agron. J., 20, 1193-1196.

WELLS, s. A. and SKOROPAD, W. P. 1963. Inheritance of reaction to Rynchosporium secalis in barley. Can. F. Pl. Sci., 43, 184-187.

wILliams, R. J. 1969. Physiologic races of Rhynchosporium secalis on cultivated barley in Britain. Ph.D. Thesis, Univ. Reading. 